\title{
Impact of intellectual capital on financial performance in the pharmaceutical industry in Iran
}

\author{
Jalal Jasour ${ }^{1 *}$, , Firoz shagagi ${ }^{2}$ Sogra Rezazadeh ${ }^{1}$ \\ ${ }^{I}$ Faculty of Accounting Islamic Azad University, Parsabad, Iran \\ ${ }^{2}$ Centeral Organization of Rural Cooperatives of Iran \\ * Corresponding author E-mail: jasor@iaupmogan.ac.ir
}

\begin{abstract}
In the era of knowledge-based economy, organizations make use of two distinct sources for value creation and profit, i.e., tangible resources and or intangible resources. On the other hand, it is believed that intellectual capital could be better than the material and physical capital in explaining financial performance indicators of companies. Regarding this background, the present research, through an investigation done on the performance of 22 pharmaceutical companies in the period of 2004-2008, revealed that companies' efficient and optimal use of material and intellectual resources affects their profitability index. Also, efficiency has a negative effect on the productivity of human capital and productivity of structural capital has a positive impact on equity. Finally, no evidence was found about the hypothesis that the market value changes of companies can be attributed to the performance of intellectual capital and it seems that Iranian pharmaceutical market still continues to be sensitive to material capital more than intellectual capital.
\end{abstract}

Keywords: intellectual capital, human capital, financial performance, the pharmaceutical industry.

\section{Introduction}

It seems that traditional accounting reports can neither reflect the real value flowing from the intangible assets and intellectual capital of the company nor notice the gap between market and book value of companies [7,8]. Intellectual capital consists of materials such as knowledge, information, intellectual property and experience that can be used for wealth creation [30]. Research about intellectual capital, involves trying to understand the roots of value creation in companies [9]. This value shows how existing material and intellectual resources have been used by the enterprise [10]. A quantitative method for measuring the efficiency of material and intellectual capital is the added value intellectual coefficient or VAIC [24, 25]. This coefficient determines how much new value and profit are created that for each currency in which the material and intellectual resources are invested. If the value of this coefficient is more, then appropriate and desirable use of the material and intellectual resources have been made.

The present study seeks to determine the contribution of intellectual capital in explaining the performance of pharmaceutical companies in Iran. Most pharmaceutical companies are rich in terms of intellectual capital due to having knowledgeable and talented employees, large investments in research and development, and ownership of inventions and diverse scientific discoveries. Therefore, the debate is whether pharmaceutical companies are efficient and strong in the use of their rich intellectual capital to improve financial performance? In other words, how are these intangible assets involved in explaining the financial performance of pharmaceutical companies?

\section{Intellectual capital: existence and dimensions}

Intellectual capital is composed of non-physical basis of the company's value creation related to the capabilities of employees, organizational resources, operational procedures and communication with relevant stakeholders [20] and determines the value of any company in the market environment. From the accounting perspective, intellectual capital equals the margin of market and bookkeeping values of a company $[6,9]$ and despite the failure to be put on the balance sheet due to the hidden nature [27], has the potential to become a profit [16]. Market value refers to the price of assets 
traded in a competitive environment and the price that the market environment determines for the activities and products.

In a wider and accepted view, intellectual capital consists of three dimensions: human, structural and customer [3]. Human capital can include items such as knowledge, education, skill, innovation and problem solving ability. Although, human capital is considered as the basis and heart of intellectual capital, it is not under the property of companies does because it will immediately disappear as soon as staff leaves the company [4].

Structural capital includes all non-human reserves of knowledge in companies and as Macroy [22] believes everyday when employees leave a company it remains in the company. Advinson and Malone [9] believe that this capital consists of elements such as hardware and software, databases, structure, patents, trademarks and all of the organizational capacity to support the company's productivity. Ultimately, the essence of customer capital in science lies in the marketing and communication channels with customers [5]. New definitions extend the concept of customer capital to communication capital that includes knowledge in the relationship the company has with customers, competitors, suppliers and government agents [4].

\section{Measure of intellectual capital}

Perhaps the most important challenge in the field of intellectual capital is the measurement methods and collection of relevant data. Methods of measuring intellectual capital can be divided into two categories: financial and non-financial methods. Non-financial methods deal with the understanding of employees, managers and stakeholders from the intellectual capital options like balanced score. In this method real and objective values are not paid attention to, so, first, it is difficult to establish cause and effect relationship and cannot be generalized; Secondly, due to the subjective nature, they are usually associated with bias and distortion,. And finally a comparative analysis between companies cannot exist $[8,19]$. In contrast, financial methods are based on the monetary value of intangible assets and because of their use of real and objective values, comparative analysis of different levels are possible. However, relying on past data is considered as the fundamental problem of financial methods. Among these methods, "calculated intangible value" [28], and "added value intellectual coefficient" [24, 25] can be pointed out. The first method is used for determining the monetary value of intellectual capital, and the second method is used to determine optimal and efficient use of capital in creating value for companies. Considering that in the present study, the second method was used to measure intellectual capital efficiency, it will be described later.

Added value intellectual coefficient (VAIC), invented by Ante Pouly, is an analytical tool for performance measurement and simultaneously measures the effectiveness of companies in creating value through the physical and intellectual (Human and structural) resources. The fundamental theme of VAIC technology is that companies use their existing tangible and intangible resources simultaneously to produce products and provide services. If the amount of added value intellectual coefficient (VAIC) is more, it means that partners have made the best use of potential resources (tangible and intangible) in order to create value [25, 32]. The amount of this technique is comparable among companies and thereby it can be reported to external stakeholders [1].

\section{Formulating hypotheses and conceptual model}

The main goal of the current study is to evaluate the efficacy of pharmaceutical companies in the use of the material and intellectual capital and investigating the effect of efficiency of these resources on their financial performance. It must be accepted that the value of financial performance indicators (market value, profitability, productivity and equity) is not solely due to material and physical capital is the first period; but it can be influenced by intangible factors such as intellectual capital that is not normally included in financial reports of companies. For example, cash or having the best machinery is not enough to ensure profitability; but there should be powerful people to use these facilities efficiently. In addition, several studies have emphasized the role of intellectual capital efficiency in the financial performance of companies. For example, Tan et al., [29], through a study done on 150 Corporate in Singapore, showed that intellectual capital is associated with the future performance; however, the contribution of intellectual capital is different depending on the type of industry. Tavsytga and Toulougouvarava [31] concluded that the components of intellectual capital (human and structural) have a significant role in explaining the performance of Russian small companies. Kamas [17], through studying superior pharmaceutical companies, revealed that human capital has a large impact on profitability and productivity. Fiyers and Astanbank [11] studied 65 companies in South Africa. They realized that intellectual capital can explain and predict changes in profitability and productivity of companies. Based on extensive research done to investigate the effect of intellectual capital on corporate performance, researchers should look for evidence about the important role intellectual capital has in the pharmaceutical industry in Iran in regard to explaining the performance. So the main hypothesis of this study is as follows: 
Added value intellectual coefficient (VAIC) has an impact on the performance of pharmaceutical companies.

On the other hand, VAIC technique is a criterion of both physical and mental ability of a company, but if investors place different values for the three aspects of this model, three-aspect model will have more explanatory power compared to single-sided model. In addition, dividing company resources into used capital and human and structural capital with source-oriented approach is compatible with business [26]. In this perspective, a company is considered as a set of physical and intangible assets and capabilities. The advocates of resource-oriented theory believe that both tangible and intangible resources of companies are major stimulus of their competitiveness and performance. Used capital represents the tangible resources and human and structural capitals are indicators of intangible resources.

Therefore, sub-hypothesis can be stated as:

- The human capital efficiency has an impact on the financial performance of pharmaceutical companies.

- The capital structure efficiency has an impact on the financial performance of pharmaceutical companies.

- The physical capital efficiency has an impact on the financial performance of pharmaceutical companies.

Some studies $[15,14,11,10,23]$ showed that the relationship between intellectual capital and financial performance may be overshadowed by issues industry, risk, firm size and the ratio of debt. Since this study was done only in one industry (i.e., pharmaceutical industry), factors such as firm size and debt ratio have been considered as control variables. Research Titles and relationships between variables are available in Figure 1.

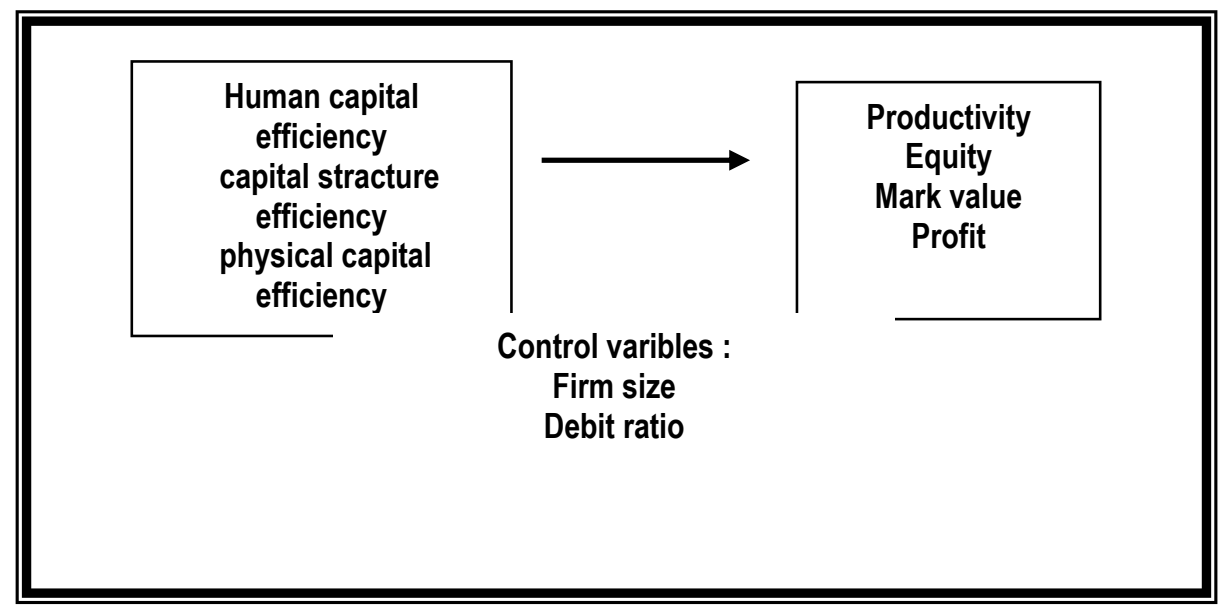

\section{Research method}

The current experimental study seeks to measure the quality of material and intellectual capital in the pharmaceutical industry in Iran and to investigate their effect on financial performance indicators of companies in the industry in focus. Statistical population of the research is all active companies in Iran's pharmaceutical industry from which about 26 companies that are present in the stock exchange were selected as the sample. Required data were extracted from the official financial reports (balance sheet, profit and loss) for the period of 2004-2008 available in "Tadbir pardaz" and "Rahavard novin" software's (two iranian accounting softwares). Selection criteria for companies is the availability of financial data for the entire five-year period based on which four companies, due to lack of financial information for the desired period, were not analyzed and eventually 22 companies remained. Also, the performance of each company in each year was considered as an observation and therefore it can be said that the final sample for this study was 110 firmyears cases.

Measuring efficiency of companies' use of tangible and intangible resources was done through VAIC technique. Calculation process of VAIC is done with the subtraction outputs (gross income) from inputs (total expenditure), value added is calculated according to this formula:

1) $\mathrm{VA}=\mathrm{R}+\mathrm{T}+\mathrm{DIV}+\mathrm{WS}+\mathrm{D}$

In the above formula, $\mathrm{R}$ represents retained earnings, $\mathrm{T}$ represents taxes, DIV is the symbol of dividend, WS is the symbol of salary and finally D indicates depreciation. It should be noted that salary should not be considered as the initial cost; rather these costs are considered a kind of investment because of having an active role in the company's value creation. Moreover, given the fact that the sum of retained earnings, tax and dividend is called operating profit $(\mathrm{OP})$, the above formula can also be written as follows:

$\mathrm{VA}=\mathrm{OP}+\mathrm{WS}+\mathrm{D}$

In the second stage, human capital efficiency (HCE), which represents the optimum use of human assets, is obtained through the ratio of the added value to human capital (HC). Indicator of human capital is the cost payroll: 
2) $\mathrm{HCE}=\mathrm{VA} / \mathrm{HC}$

In the third and fourth stages, first the capital structure was calculated by subtracting the added value (gross income) from human capital; then capital structure efficiency (SCE) that describes the efficient and optimal usage of infrastructure and operational processes is obtained through dividing capital structure (SC) by added value (gross income):

3) $\mathrm{SC}=\mathrm{VA}-\mathrm{HC}$ and 4) $\mathrm{SCE}=\mathrm{SC} / \mathrm{VA}$

In the fifth stage, the capital employed efficiency (CEE) is calculated through dividing added value (gross income) by capital employed (CE) which is also referred to operational assets. This Capital is total capital brought by shareholders and long-term debt that was spent for company's fixed and current assets. It should be noted that the index of employed capital is the book value of assets. In the sixth step, the intellectual coefficient of added value is obtained through adding human capital efficiency (HCE), structural capital efficiency (SCE) and capital employed efficiency (CEE):

5) $\mathrm{CEE}=\mathrm{SC} / \mathrm{VA}$ and 6) $\mathrm{VAIC}=\mathrm{HCE}+\mathrm{SCE}+\mathrm{CEE}$

In this study, generality and components of VAIC are considered as independent variables. Also, the four measures of financial performance (profitability, productivity, return on equity and market value) were considered as dependent variables. Profitability, which is also called return on assets, is obtained by dividing the net profit by equity. Productivity index or asset turnover ratio is the ratio of revenue (sales) to the book value of assets. Return on equity shows how much profit is gained by the company for per Rail investment of shareholders. Finally, market value reflects the total ratio of market value to book value of net assets (equity) that is calculated by multiplying the share price by the number of issued shares. On the other hand, leverage (debt ratio) and firm size were considered as control variables. Since the relationship between intellectual capital and financial performance of a company may be overshadowed by factors such as firm size, industry type and ratio of debt, it is necessary to remove the impact of these neutral factors from the regression analysis. It is worth noting that the ratio of company's debt is obtained through dividing the debt by total assets and firm size is measured by the logarithm of firm market value.

\section{Results}

The mean and standard deviation of VAIC and its components for each of the selected pharmaceutical companies in the five-year period have been displayed in table 1. From this table, it can be argued that in terms of efficiency in the use of physical and intellectual resources, Farabi, Pars, Daroupakhsh, Zahravy and companies are the first to fifth grades respectively in the five-year period. For example, intellectual performance of added value in Farabi and Jabber Ebn Hayyan Pharmaceutical Companies was 25.36 and 14.35 million Rials, respectively. Regarding the interpretation of average values it can be claimed that Farabi company created about 36 Rials value for every one Rial investment in physical and intellectual resources in the five-year period among which 32.22 Rials is related to the performance of its intellectual capital. In addition, based on the mean of VAIC components it can be said that the share of human capital (10.36) in the creation of value for pharmaceutical companies, is more than capital structure (0.86) and physical structure $(0.31)$.

Also in Figure 2, value creation process of pharmaceutical companies from the perspective of VAIC has been shown during 1383-87 period. The amounts of effectiveness of material and intellectual capitals of these companies in the mentioned five years were: $11.91,12.41,12.1,11.1$, and 28.10, respectively. As these amounts imply, the efficiency of material and intellectual capitals of pharmaceutical companies in the years of 1383 to 1386 have increased with the same rate, but in 1387 this coefficient was in the descending mode. This fact requires a serious discussion and reflection by those involved in Iran's pharmaceutical industry.

Just being efficient in using resources is not enough; rather companies must also show the ability of value creation [13]. To explain the financial performance of companies on the physical and intellectual resources, hierarchical multiple regression test was used. To do so, first the control variables and then the independent variables were entered into regression models the results of which are shown in table 2 . Regarding the productivity index, it was revealed that 2.3 of the variance of the index are contributed to the control variables, and about 77.5 of it is contributed to the material and intellectual capitals. It can be concluded that the predicting power of variance of the productivity of material and intellectual capitals is more than control variables. Also, human capital efficiency has a significant negative relationship and physical capital efficiency has a significant positive relationship with productivity and there was no significant relationship between indicators of productivity and capital structure efficiency.

Increasing the explanatory power of equity index from 0.276 to 0.384 would indicate that $28 \%$ of the index changes significantly were influenced by the size and the ratio of corporate debt, and the remaining (11 percent) is due to the material and intellectual capitals. The standardized beta coefficients show that the control variables have significant positive impact on equity returns, moreover; they have more explanatory power than physical and intellectual capitals. Also, only the structural capital efficiency and physical capital efficiency have a significant positive relationship with equity returns and in the meantime, the effect of structure capital efficiency on performance index is more than physical capital efficiency. 


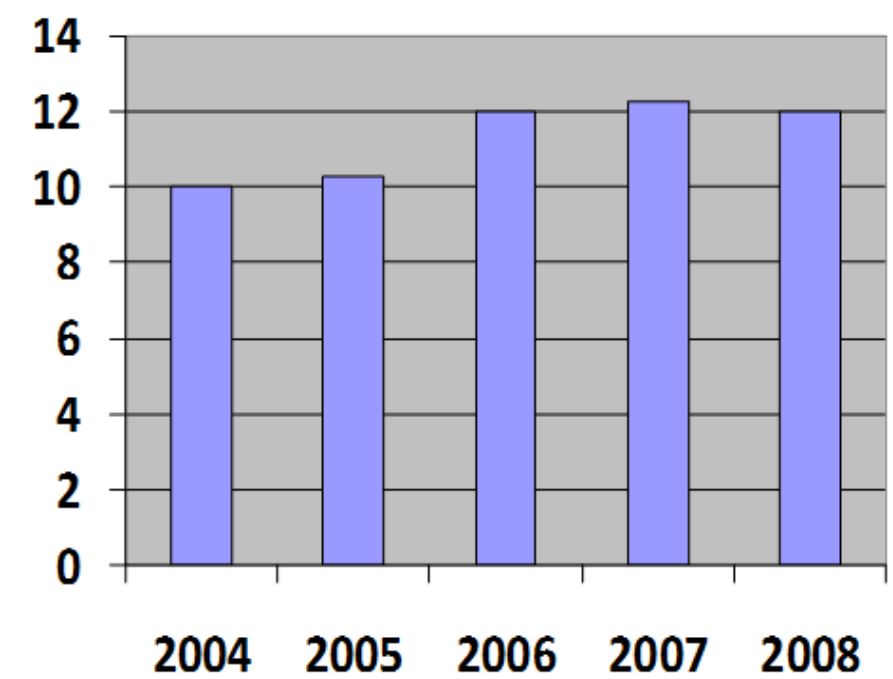

Fig. 2: The mean of VAIC pharmaceutical companies in the years of 2004-2008

Just being efficient in using resources is not enough; rather companies must also show the ability of value creation [13]. To explain the financial performance of companies on the physical and intellectual resources, hierarchical multiple regression test was used. To do so, first the control variables and then the independent variables were entered into regression models the results of which are shown in table 2. Regarding the productivity index, it was revealed that 2.3 of the variance of the index are contributed to the control variables, and about 77.5 of it is contributed to the material and intellectual capitals. It can be concluded that the predicting power of variance of the productivity of material and intellectual capitals is more than control variables. Also, human capital efficiency has a significant negative relationship and physical capital efficiency has a significant positive relationship with productivity and there was no significant relationship between indicators of productivity and capital structure efficiency.

Increasing the explanatory power of equity index from 0.276 to 0.384 would indicate that $28 \%$ of the index changes significantly were influenced by the size and the ratio of corporate debt, and the remaining (11 percent) is due to the material and intellectual capitals. The standardized beta coefficients show that the control variables have significant positive impact on equity returns, moreover; they have more explanatory power than physical and intellectual capitals. Also, only the structural capital efficiency and physical capital efficiency have a significant positive relationship with equity returns and in the meantime, the effect of structure capital efficiency on performance index is more than physical capital efficiency.

In the next step, increasing the market value from 0.343 to 0.418 showed that 34 percent of market value changes significantly are related to the size and predicted debt ratio and the remaining is related to physical and intellectual capitals. Thus, while the standard beta coefficients of the size of the company and debt ratio are both positive and significant, the results suggest that the market value variance explaining power of the components of the control variables is more than physical and intellectual capitals. On the other hand, the beta coefficients show that only physical capital efficiency has significant positive relationship with market value, and the relationship between human capital and structural performance with this indicator is not significant.

Finally, the findings related profitability index show that the $\% 81$ of the variance in the performance index are forecast by the physical and intellectual capital. Standardized beta coefficients suggests that, first, control variables have no significant effect on the profitability of pharmaceutical companies and, also, all components of VAIC have significant positive impact on profitability. Greatest amount of variance explaining belongs to the physical capital efficiency with the structural capital efficiency and human capital efficiency being in the next orders.

\section{Conclusions and recommendations}

As noted earlier, the present study seeks to predict the performance indicators of pharmaceutical companies in Iran using both tangible and intangible resources. Test results of multiple regression test revealed that only human capital efficiency has a negative relation with productivity index. To explain this negative relationship, it should be said that paying attention to human capital efficiency results in reducing productivity and waste of cost in pharmaceutical companies; that is, the companies that are looking to increase productivity through the deployment of physical and tangible assets normally do not spend a lot of effort to efficiently use the of human resource capabilities. On the other 
hand, companies that emphasize the abilities and knowledge of human resources might pay little attention to efficient use of tangible and physical assets.

Table 1: Average physical performance, intellectual capital and pharmaceutical companies in the range of 2004-2008

\begin{tabular}{|c|c|c|c|c|c|c|c|c|}
\hline \multirow{2}{*}{$\begin{array}{c}\text { Company's } \\
\text { name }\end{array}$} & \multicolumn{2}{|c|}{$\begin{array}{c}\text { Structural capital } \\
\text { performance }\end{array}$} & \multicolumn{2}{|c|}{$\begin{array}{l}\text { human capital } \\
\text { performance }\end{array}$} & \multicolumn{2}{|c|}{$\begin{array}{l}\text { Physical capital } \\
\text { performance }\end{array}$} & \multicolumn{2}{|c|}{ VAIC } \\
\hline & $\mathrm{M}$ & SD & $\mathrm{M}$ & SD & $\mathrm{M}$ & SD & $\mathrm{M}$ & SD \\
\hline Alborz Darou & $0 / 3270$ & $0 / 0867$ & $0 / 5843$ & $1 / 8592$ & $0 / 0211$ & $0 / 8924$ & $1 / 9550$ & $10 / 8037$ \\
\hline Iran Darou & $0 / 3008$ & $0 / 0676$ & $6 / 5444$ & $1 / 5991$ & $0 / 0407$ & $0 / 8393$ & $1 / 7011$ & $7 / 6845$ \\
\hline Pras Darou & $0 / 3279$ & $0 / 1376$ & $24 / 8238$ & $10 / 9535$ & $0 / 0261$ & $0 / 9515$ & $11 / 0833$ & $26 / 1032$ \\
\hline Tehran Darou & $0 / 1525$ & $0 / 0559$ & $2 / 8527$ & $0 / 4136$ & $0 / 0511$ & $0 / 6436$ & $0 / 5060$ & $3 / 6487$ \\
\hline $\begin{array}{l}\text { Tehran Shimi } \\
\text { Darou }\end{array}$ & $0 / 0594$ & 0/0097 & $0 / 2046$ & 0/4399 & $0 / 0286$ & 0/7598 & $0 / 4727$ & $5 / 0238$ \\
\hline Aboureyhan & $0 / 2226$ & $0 / 0617$ & $8 / 7012$ & $1 / 0347$ & $0 / 0142$ & $0 / 8837$ & $1 / 0903$ & $9 / 8075$ \\
\hline Osveh Darou & $1 / 2914$ & $0 / 4479$ & $7 / 5116$ & $3 / 6643$ & $0 / 0800$ & $0 / 8371$ & $4 / 1760$ & $9 / 6401$ \\
\hline Amin Darou & $0 / 1780$ & $0 / 0388$ & $5 / 8888$ & $1 / 2174$ & $0 / 0340$ & $0 / 8246$ & $1 / 2896$ & $6 / 8914$ \\
\hline Eksir Darou & $0 / 2755$ & $0 / 344$ & $12 / 6257$ & $1 / 3390$ & $0 / 0082$ & 0/9201 & $1 / 3596$ & $13 / 8214$ \\
\hline $\begin{array}{l}\text { Damelran } \\
\text { Darou }\end{array}$ & $0 / 2696$ & 0/0298 & $10 / 9659$ & $1 / 4787$ & $0 / 0128$ & 0/9074 & $1 / 4998$ & $12 / 1430$ \\
\hline Razak Darou & $0 / 2288$ & $0 / 0517$ & $6 / 7403$ & $3 / 1524$ & $0 / 0603$ & $0 / 8305$ & $3 / 2583$ & $7 / 7996$ \\
\hline Abidi Darou & $0 / 3004$ & $0 / 0136$ & $8 / 6183$ & $0 / 8755$ & $0 / 0119$ & $0 / 8830$ & $0 / 8979$ & $9 / 8017$ \\
\hline Sobhan Darou & $0 / 3282$ & $0 / 1147$ & $6 / 5778$ & $1 / 3305$ & $0 / 0351$ & $0 / 8428$ & $1 / 2943$ & $7 / 7488$ \\
\hline $\begin{array}{c}\text { Zahravi } \\
\text { Darou }\end{array}$ & $0 / 3037$ & $0 / 0228$ & $13 / 7784$ & $6 / 9573$ & $0 / 0637$ & $0 / 9022$ & $7 / 1322$ & $14 / 9843$ \\
\hline Farabi Darou & $0 / 2261$ & $0 / 0183$ & $35 / 0581$ & $8 / 2010$ & $0 / 0087$ & $0 / 9699$ & $8 / 2296$ & $36 / 2541$ \\
\hline $\begin{array}{l}\text { Loghman } \\
\text { Darou }\end{array}$ & $0 / 1682$ & $0 / 0150$ & $5 / 6761$ & $1 / 3063$ & $0 / 0564$ & $0 / 8136$ & $1 / 3789$ & $6 / 6579$ \\
\hline $\begin{array}{c}\text { Jabber Ebn } \\
\text { Hayyan } \\
\text { Darou }\end{array}$ & $0 / 2856$ & 0/0393 & $13 / 1536$ & $3 / 6079$ & $0 / 0214$ & $0 / 9193$ & $3 / 6379$ & $14 / 3585$ \\
\hline Kousar Darou & $0 / 1747$ & $0 / 0757$ & $8 / 8660$ & $0 / 0864$ & $0 / 0141$ & $0 / 8858$ & $1 / 1151$ & $9 / 9266$ \\
\hline Sina Darou & $0 / 4251$ & $0 / 1545$ & $10 / 2229$ & $0 / 8719$ & $0 / 0083$ & $0 / 9016$ & $0 / 9528$ & $11 / 5496$ \\
\hline Rouz Darou & $0 / 3897$ & $0 / 0597$ & $5 / 1321$ & $0 / 4487$ & $0 / 0165$ & $0 / 8040$ & $0 / 5194$ & $6 / 3258$ \\
\hline $\begin{array}{l}\text { Darou } \\
\text { Maerial }\end{array}$ & $0 / 3587$ & $0 / 1545$ & $14 / 9545$ & $5 / 8994$ & $0 / 0265$ & $0 / 9251$ & $6 / 0710$ & $16 / 2384$ \\
\hline $\begin{array}{c}\text { Daroupaksh } \\
\text { Factory }\end{array}$ & $0 / 2818$ & $0 / 0315$ & $5 / 5246$ & $0 / 6762$ & $0 / 8164$ & $0 / 8164$ & 0/7306 & $6 / 6229$ \\
\hline
\end{tabular}

Table 2: Hierarchical multiple regression elements of performance indicators to the VAIC

\begin{tabular}{|c|c|c|c|c|c|c|c|c|}
\hline \multirow{2}{*}{ Varible } & \multicolumn{2}{|c|}{ Productivity } & \multicolumn{2}{c|}{ Equity } & \multicolumn{2}{c|}{ Market value } & \multicolumn{2}{c|}{ Profitability } \\
\cline { 2 - 9 } & $\beta$ & sign & $\beta$ & sign & $\beta$ & sign & sign & Sign \\
\hline lever & $-/ 167$ & $0 / 125$ & $0 / 503$ & $0 / 000$ & $0 / 563$ & $0 / 000$ & $-0 / 311$ & $0 / 002$ \\
\hline size & $0 / 028$ & $0 / 795$ & $0 / 518$ & $0 / 000$ & $0 / 576$ & $0 / 000$ & $0 / 182$ & $0 / 070$ \\
\hline $\begin{array}{c}\text { Coefficient of } \\
\text { determination }\end{array}$ & $0 / 033$ & & $0 / 276$ & & $0 / 343$ & & $0 / 183$ & \\
\hline Fisher & $1 / 82$ & & $20 / 36$ & & $27 / 91$ & & $11 / 95$ & $0 / 013$ \\
\hline lever & $0 / 151$ & $0 / 004$ & $0 / 615$ & $0 / 000$ & $0 / 670$ & $0 / 000$ & $0 / 214$ \\
\hline Size & $-0 / 08$ & $0 / 201$ & $0 / 293$ & $0 / 010$ & $0 / 505$ & $10 / 00$ & $0 / 004$ & $0 / 766$ \\
\hline structural capital efficiency & $0 / 953$ & $0 / 000$ & $0 / 256$ & $0 / 003$ & $0 / 283$ & $0 / 001$ & $0 / 974$ & $0 / 000$ \\
\hline human capital efficiency & $-0 / 044$ & $0 / 048$ & $0 / 025$ & $0 / 824$ & $-0 / 056$ & $0 / 612$ & $0 / 027$ & $0 / 046$ \\
\hline structural capital efficiency & $0 / 048$ & $0 / 5$ & $0 / 293$ & $0 / 022$ & $0 / 119$ & $0 / 331$ & $0 / 088$ & $0 / 000$ \\
\hline $\begin{array}{c}\text { Explaining coefficient } \\
\text { change }\end{array}$ & $0 / 775$ & & $0 / 109$ & & $0 / 075$ & & $0 / 809$ & \\
\hline Fisher change & $1399 / 66$ & & $6 / 123$ & & $4 / 47$ & & & $3425 / 2$ \\
\hline
\end{tabular}


The findings of the current research confirmed that human and physical capital efficiency has a significant positive relation with equity; but the relationship between human capital efficiency and return on equity is not significant. Interestingly, structural capital efficiency, compared with physical capital efficiency, has a greater impact on this performance index. In fact, changing physical and financial assets to structural assets (i.e., use of material resources in designing and creation of processes, and work systems and infrastructure) besides becoming added value, leads to improving equity efficiency of pharmaceutical companies is returns. Market value, as the third performance index is related only with physical capital efficiency, and both control variables (debt ratio and firm size) also have a significant effect on this index. In fact, we can say that the market of the pharmaceutical industry, did not spend much sensitivity to the capabilities of companies in profitability through intellectual property, and has primarily focused on companies' physical assets, and assesses them according to physical and material capital. Such a situation can be the result of not providing the performance of intangible assets in the financial statements of companies and also because owners used to rely on the underlying physical intangible assets. Finally, the findings showed that human, structural and physical capital efficiency has a significant positive impact on company productivity; however, the material and physical assets still have a greater impact on profitability, compared to intangible assets.

The results and findings of the current study are consistent and compatible with some similar studies, but are in conflict with others. For example, although some researchers [23, 8, 25] emphasized the role of intellectual capital in explaining the difference between book and market values of companies, the current study, like some similar studies [15, 14, 10], has not find any signs regarding the relationship between intellectual capital and market value of companies. On the other hand, as some researchers $[34,30,26,17,12,10]$ confirm the role of intellectual capital in explaining the profitability, the current study also showed the mentioned relationship.

This study includes significant themes for practitioners and managers of pharmaceutical companies and researchers who are interested in the topic of intellectual capital. First, the efficiency of pharmaceutical companies in the use of tangible and intangible resources has increased in the years 2004-2008 slightly and continuously, but in 2008, it is declining that requires serious reflection of the authorities in this field. Second, the mean of human capital and structural capital efficiency of pharmaceutical companies in years 2004-2008 was more compared to physical and material capital efficiency and it can be claimed that Iranian pharmaceutical companies have made the best use of power and knowledge of staff, infrastructure and work processes, and simply stated their intellectual capital. Third, despite to the slogan "our most important asset in the current era is staff" has resonated in many companies, investors still base their investments solely on physical assets in companies. Therefore, it is necessary to include the intellectual capital indicators in the financial reports of companies and this information should be available to people who need it for investment decisions. Fourth, it seems that companies in the pharmaceutical industry, when considering a field, ignore and forget the other. For example, paying attention to the efficient use of material resources and physical and material facilities, and reducing and controlling costs, pharmaceutical companies ignore dimensions such as improving staff skills and knowledge, though, considering both fields can make the companies succeed and flourish in the competitive environment. Fifth, the process of this study helps pharmaceutical companies, through making use of VAIC methodology, first, used to calculate the efficiency of its intellectual capital, second, to compared it with material capital efficiency, and ultimately, to include them in other financial statements for the sake of clarification and shareholders and investors' awareness.

For future research, it is suggested that the annual analysis, comparing the growth of intellectual capital sectors and subsequently financial indicators can be good topics for future research in the pharmaceutical industry to approve or reject the findings of this research. In addition, comparative analysis of themes in different industries can have significant topics for the country's economy and trade.

\section{References}

[1] Antola, J., Kujansivu, P. and Lonnqvist, A. (2005). Management accounting for intellectual capital, Proceedings of the 7th Conference on Manufacturing Accounting Research, Tampere, May 30-June 1

[2] Barney, J.B. (1991). Firm resources and sustainable competitive advantage. Journal of Management, 17 (1), $99-120$.

[3] Bontis, N. (1998). Intellectual capital: an exploratory study that develops measures and models. Management Decision, 36 (92), $63-76$.

[4] Bounties, N. (1999). Managing organizational knowledge by diagnosing intellectual capital: framing and advancing the state of the field. International Journal of Technology Management, 18 ( 5-8), 433-462.

[5] Bounties, N., Keow, W.C. \& Richardson, S. (2000). Intellectual capital and the nature of business in Malaysia. Journal of intellectual capital, $1(1), 85-100$.

[6] Brooking, A. (1996). Intellectual Capital - Core Asset for the Third Millennium Enterprises. London: International Thomson Business Press.

[7] Canibano, L, Ayuso, M and Sanchez, P (2000). Accounting for intangibles: a literature review. Journal of Accounting Literature, 19, 102-130.

[8] Chen, M.C., Cheng, S.J. \& Hwang, Y (2005). An empirical investigation of the relationship between intellectual capital and firms' market value and financial performance. Journal of Intellectual Capital, 6 (2), 159-76.

[9] Edvinsson, L. \& Malone, M. (1997). Intellectual Capital: Realizing Your Company’s True Value by Finding Its Hidden Brainpower. New York: HarperCollins.

[10] Firer, S. \& Stainbank, L. (2003). Testing the relationship between intellectual capital and a company's performance: evidence from South Africa. Meditari Accountancy Research, 11, 25-44. 
[11] Firer, S. \& Williams, S.M. (2003). Intellectual capital and traditional measures of corporate performance. Journal of Intellectual Capital, 4 (3), 348-60

[12] Ghosh, S \& Mondal, A (2009). Indian software and pharmaceutical sector IC and financial performance. Journal of Intellectual Capital, 10 (3), 369-88.

[13] Goh, P.C. (2005). Intellectual capital performance of commercial banks in Malaysia, Journal of Intellectual Capital, 6 (3), $385-96$.

[14] Hang Chan, K (2009). Impact of intellectual capital on organizational performance: An empirical study of companies in the Hang Seng Index (Part-1). The Learning Organization, 16 (1), 4-21.

[15] Hang Chan, K. (2009). Impact of intellectual capital on organizational performance: An empirical study of companies in the Hang Seng Index (Part-2). The Learning Organization, 16 (1), 22-39.

[16] Harrison, S., \& Sullivan, P.H. (2000). Profiting from intellectual capital: learning from leading companies. Journal of Intellectual Capital, 1, $33-46$.

[17] Kamath, G.B (2008). Intellectual capital and corporate performance in Indian pharmaceutical industry. Journal of Intellectual Capital, 9 (4), 684-704.

[18] Kannan, G \& Aulbur, W. (2004). Intellectual capital: measurement effectiveness. Journal of Intellectual Capital, 53 (3), $389-414$.

[19] Kujansivu, P., \& Lonnqvist, A. (2007). Investigating the value and efficiency of intellectual capital. Journal of Intellectual Capital, 8 (2), 272-87.

[20] Lonnqvist, A. (2004). Measurement of intangible success factors: case studies on the design, implementation and use of measures (doctoral dissertation). Publication 475, Tampere University of Technology, Tampere.

[21] Marr, B., Schiuma, G., \& Neely, A. (2002). Assessing strategic knowledge assets in eBusiness. Internationa 1 Journal of Business Performance Management, 4 (2-3-4), 279-95.

[22] McElroy, M.W. (2002). Social innovation capital. Journal of Intellectual Capital, 3 (1), 30-39.

[23] Najibullah, S. (2005). An empirical investigation of the relationship between intellectual capital and fir msm arket value and financial performance in context of commercial banks of Bangladesh. Bangladesh: Independent University.

[24] Pulic, A. (1998). Measuring the performance of intellectual potential in knowledge economy www.measuring-ip.at/OPapers/Pulic/ Vaictxt/vaictxt.html

[25] Pulic, A. (2000). VAICe - an accounting tool for IC management. . Retrieved from www. measuring-ip.at/Papers/ham99txt.html

[26] Riahi-Belkaoui, A. (2003). Intellectual capital and firm performance of us multinational firms, Journal of Intellectual Capital, 4 (2), 215-26.

[27] Skandia (1994). Visualizing Intellectual Capital in Skandia, intellectual capital supplement. . Retrieved from www.skandia.se.

[28] Stewart, T.A. (1997). Intellectual Capital: The New Wealth of Organizations Doubleday/Currency. New York: NY.

[29] Tan, H.P., Plowman, D. \& Hancock, P. (2007). Intellectual capital and financial return of companies. Journal of Intellectual Capital, 8 (1), 7695.

[30] Ting, I.W \& Lean, H.H. (2009). Intellectual capital performance of financial institutions in Malaysia. Journal of Intellectual Capital, 10 (4), 588-99.

[31] Tovstiga, G \& Tulugurova, E (2007). Intellectual capital practices and performance in Russian enterprises. Journal of Intellectual Capital, 8 (4), 695-707

[32] Van der Zahn, M.J-L.W., Tower, G. \& Neilson, J. (2004). Intellectual Capital and the Efficiency of Value Added: Trends in the Singapore Capital Market 2000-2002. Burleigh: Poseidon Books.

[33] Williams, S.M. (2001). Is intellectual capital performance and disclosure practices related Journal of Intellectual Capital, 2 (3), $192-203$.

[34] Yalama, A. and Coskun, M. (2007). Intellectual capital performance of quoted banks on the Istanbul stock exchange market. Journal of Intellectual Capital, 8 (2), 256-71. 